\title{
SURVIVAL STRATEGIES OF RURAL FAMILY HOUSEHOLDS IN CENTRAL SERBIA
}

DOI: http://dx.doi.org/10.18509/GBP.2020.52

UDC: $334.714: 316.334 .55]: 303.83(497.11)$

\author{
Ljubica Rajković \\ Vesna Miletić-Stepanović \\ Faculty of Geography, University of Belgrade, Serbia
}

\begin{abstract}
Research of survival strategies of rural families in Central Serbia is based on an analysis of various ways of adaptation of rural family households to transformation of society in the conditions of insufficiently crystallized institutional frameworks. The basic premise in this study is that the Serbian society demonstrates rural-urban polarization and that reduced number of the state's economic actions for members of rural families leaves villages and rural dwellers left to fend for themselves. Labour or the transformation of resources, which takes place in rural everyday life, includes the following typology of economic strategies: 1. passive (elderly households); 2. strategy of formal employment working in the formal market; 3. strategy of extra work (occasional or regular work performed most often in the area of informal employment, which is the only source of income); 4. strategy of work in the agriculture sector; 5. strategy of mixed employment: a combination of two or more forms of work -strategy of formal employment and extra work, formal employment and farm work, formal employment, extra work and farm work.

The starting point is the theory of modernization and innovation, with the "modernity" being referred to as the forms of social life or organization that have emerged in Europe since the seventeenth century onwards, and whose influence has since spread throughout the world. It is also the so called "late modernity" (globalization) [2] and the transformation and changes caused by modernization and globalization.

The analysis is based on primary data that have been collected in direct interviews in rural households. The data were collected during 2018 and 2019 by a special team of researchers who participated in a large-scale study of social position of villages, rural families and rural women in Central Serbia. The study was conducted in 586 rural family households, which belong to the following districts (counties): Zlatibor, Šumadijski, Belgrade, Mačvanski, Nišavski and Rasinski.
\end{abstract}

Key words: economic strategies, rural family households, modernization, globalization, Central Serbia.

\section{INTRODUCTION}

This research discusses various ways of adaptation of rural family households to the transformation of society under the conditions of insufficiently crystallized institutional frameworks. The reduced number of the state's economic actions for the members of rural families leaves villages and rural dwellers left to fend for themselves. Rural family households, depending on the relationship between the resources and needs, are in a state of deprivation, which means that resources are insufficient to meet their needs. In order 
to survive such everyday life in rural areas, there is the need to choose, change and define economic strategies, as well as to become passive or to escape from the rural environment. How are rural family survival strategies understood in this paper? Survival strategy is a way of acquiring or earning money by family members. The focus on one's personal efforts by relying on the mixed employment strategy is present in most families in our sample, which is seen as a modern age strategy. This means that personal efforts, and not family land, is the basis of the social position in rural family households in Serbia, with women and their resources being the main example of this.

The subject of the study is the analysis of the survival strategies of rural family households in central Serbia. More specifically, the research of the personal efforts by rural families as a form of struggle for survival. The study subject so defined was analyzed based on the data that was directly collected in rural family households, through discussions with the characters of survival strategies.

The goal of the research was to identify groups of rural families who use personal efforts to transform resources and earn money for their survival. The goal was also to identify the types of strategies and their combination with family resources. Another goal was to provide a useful contribution to a more detailed insight into the survival strategies of rural families in the context of village marginalization from other social flows and the fact that villages are left to themselves and their needs. We also discussed the extent to which the strategies chosen function as a sign of rural families' distinction in everyday life.

\section{THEORETICAL APPROACH}

The theoretical framework of this paper is based on the theory of modernization and innovation, with the "modernity" being referred to as the forms of social life or organization that have emerged in Europe since the seventeenth century onwards, and whose influence has since spread throughout the world. It is also the so called "late modernity" (globalization) [2] and the transformation and changes caused by modernization and globalization.

Modernization is "the global transformation of traditional, that is, stagnant societies into dynamic systems and, as such, it entails circular cumulative processes and directed structural changes that affect all the subsystems of society" [6]. In the sociological literature, the process of modernization has two meanings: the first meaning entails that modernization is the process of shaping and expanding a particular way of life based on civic rationality (M. Weber), and the second meaning says that modernization is a process of society transformation known as urbanization, bureaucratization and industrialization. [7] states that the first modernization in Serbia began in the late 1860s (emigration of the Turks) and lasted until the World War 2. This is when the first railways and factories were built, that is, the citizenship and labor class were formed. The second modernization began in the late 1940s and lasted until the 1990s, until the collapse of socialism and the dissolution of the SFRY. In social terms, it meant the rise of the middle-class members and workers, and in technological terms it was characterized by the cars. The author further points out that both the first and second modernization are unfinished or deformed modernizations. "Traditional" society was destroyed after World War 2 by rapid industrialization. Socialist modernization was semi-modernization, transferring people massively from the agrarian sector into the industrial sector, and it was semi-modern (unfinished) as it abolished the market economy. Such modernization has failed in all Eastern European societies. It was proven that "socialism is the longest and most difficult path from capitalism to capitalism" [6]. 
The third wave of modernization began in the 1990s and is still undergoing as part of the transition period, that is, the post-socialist transformation. Transition involves three main processes: democratization (political transformation), privatization (economic transformation) and modernization (structural transformation). In Serbia, the tradition has slowed down, it is blocked, and since 1998 it is reversed - transition called the "crayfish walk" [3], [4]. In the post-socialist transformation in the form of a slow, blocked and reversed transition, Serbia's society is stuck in the process of transition from socialism to capitalism. In order to overcome the inferior position of agriculture within the economy of Serbia, and the inferior position of peasants in the social relations system, that is, the "twilight of the peasantry" [5], the following things are needed: more focus by the state, especially regarding the increase of investment in agriculture, as well as a more favorable price policy, which would have a strong stimulating effect on peasants.

\section{PREMISES}

The main premise in this study is that the Serbian society demonstrates rural-urban polarization and that reduced number of the state's economic actions for members of rural families leaves villages and rural dwellers left to fend for themselves. The members of rural family households have chosen a variety of survival strategies due to them being neglected by the state, in order to overcome the weight of their poor everyday lives. The choice of economic household strategies largely depends on the relationship between the household members' resources and needs, as well as their diligence. The following typology of economic strategies is proposed: 1. passive (elderly households); 2. strategy of formal employment - working in the formal market; 3. strategy of extra work (occasional or regular work performed most often in the area of informal employment, which is the only source of income); 4. strategy of work in the agriculture sector; 5. strategy of mixed employment: a combination of two or more forms of work -strategy of formal employment and extra work, formal employment and farm work, formal employment, extra work and farm work.

\section{RESEARCH METHOD}

The analysis is based on primary data that have been collected in direct interviews in rural households. The data were collected during 2018 and 2019 by a special team of researchers who participated in a large-scale study of social position of villages, rural families and rural women in Central Serbia. The study was conducted in 586 rural family households, which belong to the following districts (counties): Zlatibor, Šumadijski, Belgrade, Mačvanski, Nišavski and Rasinski.

\section{RESULTS AND DISCUSSION}

There are various ways of adaptation of rural family households to the transformation of society under the conditions of insufficiently crystallized institutional frameworks [1], [8]. The actions taken by the families used in our sample mostly refer to the change in lifestyles and adapting to the new conditions of society transition. These strategies mostly include the adaptation strategies in the conditions of pronounced social changes in the society of Serbia: "peasants-workers" losing their jobs and their return to the village, ignorant urban-centred policies towards the village, etc. In the process of adapting to these altered systemic conditions, a large number of households seek to secure their social existence through a variety of economic strategies, which were mainly focused on formal 
employment in the former socialism period - "peasant industrial workers", agricultural activity, or combining these two activities in mixed employment households.

However, today we are seeing the changes in the choice of economic strategies, which mostly include:

1. a diversity of economic activity by the family households, where the individual family members have multiple jobs, with different qualification levels and no employment contract;

2. extensive workload;

3. lack of resources is compensated by independent food production and rural household members are meeting their needs themselves.

\section{Rural family survival strategies depending on household resources}

The members of rural family households have chosen a variety of survival strategies due to them being neglected by the state, in order to overcome the weight of their poor daily lives. The choice of economic household strategies largely depends on the relationship between the household members' resources and needs, as well as their diligence.

The rural households resources are based on the following: 1. economic capital (income, savings, movable and immovable property: number of large and small livestock, structure of land tenure, agricultural machines: tractors and attachments, agricultural facilities, household devices and appliances, cars and other means of transport, household infrastructure: water in the house, bathroom, electricity, sewage, steam heating system, telephone, the quality of housing), cultural capital (education, values, standards, social awareness, identity), social capital (social networks that household members can use to achieve their goals, as well as the social power of household members, operationalized by household size and family type) and human capital (age and number of household members capable of performing the household activities, household heir, workforce). The existing household resources should make it possible to meet the financial, cultural and social needs, that is, the primary and secondary needs. Meeting these needs is uncertain and difficult to achieve in these conditions of a difficult and unbearable rural everyday life, with a low quality of life, characterized by poverty, deprivation, suffering, ambiguity - living in a subsistence economy and low social security of the peasants. Depending on the relationship between the resources and needs, rural family households are in a state of deprivation, which means that resources are insufficient to meet the needs. This type of relationship between the resources and needs can trigger the need to choose, change and define economic strategies, as well as to become passive or to escape from the rural environment.

There are three primary elements of economic activity strategies among rural household members:

1. Formal employment

2. Informal employment

3. Domestic jobs, which include economic activity intended to meet the needs of household members, and usually refers to food production, but also various craft activities: clothes sewing, clothes knitting, household devices and appliances repair, agricultural machines repair.

\section{Activities at the household level}

Due to the insufficient financial resources, self-production and self-service in rural households mostly replace market mechanisms which are otherwise there to meet these 
domestic needs. Labour or the transformation of resources, which takes place in rural everyday life, includes the following typology of economic strategies:

1. passive (elderly households);

2. strategy of formal employment - working in the formal market;

3. strategy of extra work (occasional or regular work performed most often in the area of informal employment, which is the only source of income);

4. strategy of work in the agriculture sector;

5. strategy of mixed employment: a combination of two or more forms of work strategy of formal employment and extra work, formal employment and farm work, formal employment, extra work and farm work.

Table 1. Households by economic strategy types

\begin{tabular}{|l|c|c|}
\hline Strategy type: & $\mathrm{N}$ & $\%$ \\
\hline Passive & 32 & 5.5 \\
\hline Strategy of formal employment & 17 & 2.9 \\
\hline Strategy of extra work & 2 & 0.4 \\
\hline Strategy of work in the agriculture sector & 104 & 17.9 \\
\hline Strategy of mixed employment & 425 & 73.3 \\
\hline Total & 580 & 100.0 \\
\hline
\end{tabular}

The data in Table 1 show that the most common employment strategy in rural households is mixed employment - mixed households in almost $3 / 4$ of the households, as a combination of two or more forms of work: formal employment and extra work, entrepreneurial employment and other types of work, formal employment and agricultural work (mixed households are found on all sizes of land: $82.5 \%$ on small farms and $54.3 \%$ on large farms); extra work and agricultural work, which is explained by the maximum consumption of all available forms of capital (resources) by household members and their engagement in overcoming the low quality of everyday life). The struggle to adapt to the new living conditions and to overcome the negative impact of global social change are characterized by a high level of resources exploitation.

In regards to the mixed household modalities, the most common is the combination of formal employment, extra work and agricultural work (where the most active participants are women) - and this is a typical mixed household strategy. Based on the frequency of appearance, the next one is the "strategy of work in the agriculture sector" or agricultural households, which are represented in $17.9 \%$ of the cases and are the most frequent in the Macva district (46\%) and least frequent in the City of Belgrade (1.1\%), due to the expansion of the city limits and the conversion of agricultural land into urban and industrial land. The "strategy of work in the agriculture sector" is characterized by the food production activities and rural household members are meeting their needs themselves. As for the households focused exclusively on agricultural production, these

\footnotetext{
5 The term "extra work" implies occasional or regular jobs performed in addition to regular employment or outside formal employment status, for example: sale of agricultural products on the market, manual and handicraft work for sale, transport of goods, overtime, providing services using agricultural machinery, etc. For some individuals and households, this kind of work is the main and only source of income. These are agricultural wage workers, who do not have their own land, and consequently work as wage workers for other people, either on the farm property during the agricultural work season, or off season, if they are required for some other work.
} 
are primarily large farms: almost one half of the households own 10 or more ha, that is, $45.7 \%$, almost a third own between 8 and 10 ha of land $(31.8 \%$ ), almost $1 / 4$ own five to eight ha or $22.6 \%$ and more than $1 / 5$ own between 3 and 5 ha of land. Regarding small farms, $4.4 \%$ of the households own up to 1 ha, while every tenth household or $10.9 \%$ owns between 1 ha and 3 ha. Most of these households predominantly engage in the traditional type of diverse agricultural production, with only $2.5 \%$ of households specializing in a particular type of production - milk production, beef farm and pig farm. Almost $2 / 3$ of these households are characterized by either a very low or low financial status index, that is, $64.1 \%$, which means that farmers live in poverty and struggle for survival [8].

The "passive" strategy group (5.5\%) is dominated by elderly households, mostly women alone, with no husband, with or without permanent sources of income; as for their financial status, they rely on financial assistance from relatives, primarily their children, as well as on their own agricultural pension or the one inherited from their husband, which amounts to 80 euros. These households are very poor, their members are forgotten by the state and children, they lack resources for everything, their lives are filled with poverty, old age, sickness and deprivation, as they say, "everything is hard to supply".

Table 2. Households by economic strategy types, per district

\begin{tabular}{|c|c|c|c|c|c|c|c|c|c|c|c|c|c|c|}
\hline & \multicolumn{2}{|c|}{ Zlatibor } & \multicolumn{2}{|c|}{ Sumadijski } & \multicolumn{2}{|c|}{ Belgrade } & \multicolumn{2}{|c|}{ Macvanski } & \multicolumn{2}{|c|}{ Nisavski } & \multicolumn{2}{|c|}{ Rasinski } & \multicolumn{2}{|c|}{ Total } \\
\hline & $\mathrm{bN}$ & $\%$ & $\mathrm{bN}$ & $\%$ & $\mathrm{BN}$ & $\%$ & $\mathrm{bN}$ & $\%$ & $\mathrm{bN}$ & $\%$ & $\mathrm{bN}$ & $\%$ & $\mathrm{bN}$ & $\%$ \\
\hline Passive & 55 & 55.2 & 55 & 55.0 & 44 & 44.5 & 66 & 66.0 & 99 & $99 . .0$ & 33 & 33.1 & 332 & 55.5 \\
\hline Formal employment & 22 & 22.1 & 11 & 11.0 & 66 & 66.8 & 11 & 11.0 & 44 & 44.0 & 33 & 33.1 & 117 & 22.9 \\
\hline Extra work & -- & -- & -- & -- & -- & -- & -- & -- & 22 & 22.0 & -- & -- & 22 & 00.4 \\
\hline Agriculture & 99 & 99.4 & 223 & 223.0 & 11 & 11.1 & 446 & 446.0 & 112 & 112.0 & 113 & 113.5 & 1104 & 117.9 \\
\hline Mixed & 880 & 883.3 & 771 & 771.0 & 777 & 887.5 & 447 & 447.0 & 773 & 773.0 & 777 & 880.2 & 4425 & 773.3 \\
\hline Total & 996 & 1100 & 1100 & 1100 & 888 & 1100 & 1100 & 1100 & 1100 & 1100 & 996 & 1100 & 5580 & 1100 \\
\hline
\end{tabular}

In the group of households using the "formal employment" work strategy - nonagricultural households (2.9\%), only in five households out of a total of 17, the employed family members work in the primary job market, that is, they perform jobs that require high qualifications, their income is above average and there are opportunities for professional advancement (two class teachers, a subject teacher, an expert, a manager). However, in the majority of these households (70.6\%), all employed family members work in the secondary labor market (lower skilled non-manual and manual occupations). Households living solely on extra work were the least represented, that is, $0.4 \%$ of the households relied on this work strategy. These households base their livelihood solely on the occasional or regular work most commonly related to agricultural wage work, nonqualified manual labor, and they are characterized by high level of poverty and the struggle to survive. For these households, extra work is the main economic activity and the only solution ensuring the survival of the household members. However, extra work is more often combined with the "formal employment" work strategy in mixed households. The choice of the economic action type depends on the district in which the household is located, that is, the relationship between the household location (district) and the type of work strategy is expressed by the contingency coefficient, $\mathrm{C}=0,385$, which indicates that the household location affects the type of work the household members will engage in, as well as the specific combinations. Therefore, the mixed employment strategy was found to be the most prevalent in all districts, but it occurs most often in the City of Belgrade (87.5\%), due to the extensive possibilities of household members to take into account the city's needs and engage in certain activities accordingly: 
crafts, production and sale of food, formal employment, etc. Besides Belgrade, the same applies for Zlatibor district (83.3\%), as well as the Rasina district (80.2\%)

Furthermore, the "strategy of work in the agriculture sector" is the predominant activity in the Macvanski district - 46\% (tillage and animal husbandry), and in Sumadijski district - 23\% (animal husbandry), due to favorable environmental factors, Table 2.

\section{CONCLUSION}

Based on the analysis of the economic strategies at the level of family households used by contemporary rural families, the following conclusions can be drawn:

Different economic strategies contribute to the survival of rural family households and affect the improvement of their financial position.

The mixed employment strategy has led to numerous combinations of multiple types of strategies, that is, to the prevalence of mixed employment. This further brings insufficiently crystallized institutional frameworks.

Financial deprivation causes the offensive strategies to be used by household members to meet the basic needs, and all types of families were dominated by a variety of strategies. The share that rural women have in this wide variety of activities was indicated by the analysis of data on the position of rural women in the family division of labor: extremely high or high work burden within the family, since during the day they work on the farm, in the yard, in the house - therefore, they are engaged in domestic work, reproductive work and upbringing, and in addition to this, they are employed outside the household $[8]$.

It has been proven that changes have been made to the economic behavior of rural households and their members, which are reflected in the presence of mixed employment, which means that these contemporary families are adapting to modern trends. The factors that repel people from living in rural areas and attract them to live in the city have caused the transitional type of economic strategy to emerge, that is, the mixed employment strategy, which is the combination of several types of economic strategies and is seen as the use of urban area needs for their own interests: production and sale of food, alcoholic beverages, especially brandy, wood sales, hand knitting of sweaters, etc.

The real position of the villagers in contemporary Serbia society is best evidenced by the words of the survey participants: "A peasant always lives a difficult life; I always have to make money on my own; nobody will give me anything if I don't earn it myself"; "nobody cares about the poor peasants, they only remember us when they come to mobilize our sons, brothers, husbands ... and when the peasant asks for something nobody hears him"; "the villages are neglected ... more investment is needed in rural areas and a guarantee of purchase for agricultural products" (participants from all districts); "We work so hard and yet we live a poor life... we used to be able to buy everything we needed after selling milk from three cows -and now it's nothing"; "peasants have no money, we all lack money for everything... we have problems getting paid for our work, the state receives interest for their services but these interest rates do not apply to us; "anything we produce is cheap but anything they produce is expensive ... milk is cheaper and their products are more expensive"; "my son was in two wars and the state couldn't care less, he was wounded and remains unmarried, his life is ruined"; "anything coming from the state is expensive, while anything made by us is cheap", etc. 


\section{Acknolegments}

The article is part of the project of THE NEW CHALLENGES OF SOCIAL INTEGRATION IN SERBIA - THE CHALLENGES AND THE STAKEHOLDERS, document number 179035, whose implementation the Ministry of Science and Technological Development of Republic of Serbia

\section{REFERENCES}

[1] Babović Marija (2004): "Ekonomske strategije domaćinstava u post-socijalističkoj transformaciji Srbije", nalazi se u: Anđelka Milić (priredila): Društvena transformacija i strategije društvenih grupa: vakodnevica Srbije na početku trećeg milenijuma, Institut za sociološka istraživanja Filozofskog fakulteta u Beogradu, Beograd.

[2] Gidens Entoni (1998): Posledice modernosti, "Filip Višnjić", Beograd.

[3] Lazić Mladen, ur. (2000): Račji hod, Beograd: "Filip Višnjić".

[4] Lazić Mladen (2005): Promene i otpori. Srbija u transformacijskim procesima, IP "Filip Višnjić", Beograd.

[5] Veselinov, Dragan (1987): Sumrak seljaštva, Ekonomika, Beograd.

[6] Vujović Sreten (2002): "Urbane promene u Srbiji" u: Silvano Bolčić, Anđelka Milić (ur): Srbija krajem milenijuma: razaranje društva, promene i svakodnevni život, Institut za sociološka istraživanja Filozofskog fakulteta u Beogradu.

[7] Vujović Sreten (2002): "Urbana svakodnevica devedesetih godina" u: Silvano Bolčić (ur): Društvene promene i svakodnevni život: Srbija početkom devedesetih, ISIFF, Beograd

[8] Rajković Ljubica (2014): Društveni položaj sela, seoskih porodica i seoskih žena u centralnoj Srbiji.Beograd: Geografski fakultet. 